\title{
The Relationship Between Human Capital and the Regional Economy Productivity
}

\author{
Hendarmin $^{1 \otimes}$, Metasari Kartika ${ }^{2}$ \\ ${ }^{12}$ Economics and Business Faculty, Universitas Tanjungpura, Pontianak \\ Permalink/DOI: https://doi.org/10.15294/jejak.v12i1.19358
}

Received: October 2018; Accepted: January 2019; Published: March 2019

\begin{abstract}
The aim of this study is to measure the impact of the human capital on the economic productivity level in provinces of Kalimantan Island. The data used in this study was a panel data from 5 provinces in Kalimantan Island within 2013-2017 time periods which its study finding was analyzed using panel data regression analysis with random effect approach. The study finding explains that the human capital, measured by the education level which is the average of years of education, the health level which is life expectancy and investment has a positive effect on the productivity level of the regional economy. The analysis result also shows that the health variable has a bigger magnitude compared to the education and physical capital investment variables. Based on the result, it can be concluded that the effect of human capital is very important in increasing economic productivity in the region.
\end{abstract}

Key words : Human Capital, Productivity, Random Effect Methods.

How to Cite: Hendarmin, H., \& Kartika, M. (2019). The Relationship Between Human Capital and the Regional Economy Productivity. JEJAK: Jurnal Ekonomi dan Kebijakan, $12(1), \quad 138-152$. doi:https://doi.org/10.15294/jejak.v12i1.19358 


\section{INTRODUCTION}

In this era of globalization, the role of human capital is necessary for supporting economic activity in every region to progress. The country's ability to develop its human resources, specifically in providing skilled workforces in various fields, becomes the key to success to economic policies in every country. Education and human capitals are the two essential factors and both interlinked in contributing to economic development. The human capital is a set of resources that combines knowledge, training, and skill that relates the education quality and economic development (Islam, Ghani, Kusuma, \& Theseira, 2016).

The output increase of a country is not merely measured by capital, resources, and technology advancement, but also by its productivity growth. Productivity means a ratio between the outputs compared to the inputs. Another definition of productivity is the total of goods and services produced by a worker on each of his work hours (Mankiw, 2005). Theoretically, factors that affect productivity are physical capital, natural resources, and technology advancement. The physical modal is factors that are used to produce physically, such as land, building, machine, and other types of equipment. Those capitals utilized in various ways to support productivity. The natural resources are both raw and additional materials in producing activity. The technology advancement is comprehension in producing goods and service that is used to generate a better product.

Fuente (2011) argues that the human capital model and productivity build on a hypothesis that knowledge and skill contained in human capital directly increase productivity and increase economic capacity to develop and adopt new technology. This argument based on the theory of human capital that views higher education as an investment point whose result depends on the productivity that perceived as an alternative investment. The truth on such an assumption makes employers pay people with higher education with higher income. However, the relationship between higher education and productivity is still controversial in some literature. In a hypothesis results, it said that higher education especially has roles in improving the productivity effect which is not very strong. According to another source, it believed that higher education might help identify an individual with a certain quality but another evidence claim that higher education does not impact anything to that potential during the school period (Devadas, 2015).

The productivity level of provinces in Kalimantan shows varied growth and its trend is increasing each year. Within 2013-2017 the productivity level of provinces in Kalimantan has increased from 165.95 million rupiahs/million people in 2013 to 180.37 million rupiahs/million people in 2016. It has varied in East Kalimantan province, which its productivity decreased from 318.10 million rupiahs/million people in 2013 to 277.62 million rupiahs/million people in 2016 and increased again in 2017 to 293.93 million rupiahs/million people. The thing that might cause the decrease of productivity in East Kalimantan was the regional expansion into North Kalimantan province, which effect was the decrease of the GRDP output and the diminishing of the job vacancy. The decreasing of work opportunity would eventually reduce productivity and the economic growth a region. 
Even though the East Kalimantan province's productivity level decreased, its productivity value was higher compared to other provinces in Kalimantan Island. Three additional provinces, South Kalimantan, West Kalimantan, and Central Kalimantan, tend to have their productivity increased, while the East Kalimantan tends to decrease for three consecutive years from 2013 to 2015, but rise again for the last two years from 2016 to 2017.

As explained beforehand, the critical factor that determines productivity is human capital. The human capital, in this case, is measured by the education level - the average of years of education, health - seen from the life expectancy, and physical capital investment - the forming of Gross Fixed Capital Formation (GFCF). Within the 20132017 period, the average education years of Kalimantan people has slow growth. It has shown by the increase in the average of years of education and life expectancy that tend to have a slower growth year to year. The average of years of education of West Kalimantan is 6.9 years, South Kalimantan is 7.8 years, Central Kalimantan is 8.0 years, North Kalimantan is 8.4 years, and East Kalimantan is 9.1 years. This situation indicates that the education level in Kalimantan province has not had significant changes within five recent years and it indicates that the education level in West Kalimantan province is equivalent to junior high school. And in the last five years from 2013 to 2017, the average years of education only increases around 0.48 years. It means that it was not easy for the government to improve the average years of education of its people.

A study about the relationship between human capital and the productivity increase of the regional economy has conducted by Wang \& Liu (2016). In that study, the human capital was measured by education and health while GRDP per capita measured productivity. The study finding shows that higher education gives a significant impact on economic growth, but the secondary and elementary education does not have a significant effect economic development. The different results showed in the life expectancy of human capital which has a significant positive correlation with economic development. Education and human capital variables have linkages with economic growth (Islam et al., 2016). The result shows that there is a positive correlation between education and human capital toward the economic growth in Malaysia, and this finding is in line with the study conducted by Ismail, Saukani, \& Bakar (2014) and Ismail \& Yussof (2010).

Besides, the first health factor is one of the essentials pre-requirement for human productivity improvement, and in its turn will lead to the life development of the society. Health acknowledged as the first thing that is necessary to support someone's welfare and considered as important as the resources for a country to reach the national development goal. A study shows that good health can improve the productivity of the workforce and increase economic growth (Aldosari, Ibrahim, Manab, \& Islam, 2014). At the same time, the quality of human capital also determines whether the country has reached the higher growth in economic context or even in a broader context, which is seen by its human capital that helps a country to move towards its aim. Without a good quality of human capital, the economic and social impulses will be weaker.

Theoretically, the model that explains the relationship between human capital and 
economic growth is built based on the hypothesis that the knowledge and skills owned by humans will directly increase productivity and improve the ability of an economy to develop and adopt new technology (Fuente, 2011). Such a theoretical model includes human capital in the production function. One of the models is the Mankiw Romel and Well model (MRW Model) developed by Mankiw et al. (1992). This model modified the Solow Growth Model (Solow, 1956) by adding the accumulation of human capital in the production factor. The production function in MRW model formulated as follows:

$\mathrm{Y}(\mathrm{t})=\mathrm{K}(\mathrm{t})^{\alpha} \mathrm{H}(\mathrm{t})^{\gamma}(\mathrm{A}(\mathrm{t}) \mathrm{L}(\mathrm{t}))^{1-\alpha-\gamma}$

With $K$ as physical capital, $H$ is human capital stock, $A$ is the technology level and $L$ is the workforce. In the form of per effective workforce, the equation (1) written as follows:

$\tilde{y}(t)=\tilde{k}(t)^{\alpha} \tilde{h}(t)^{\gamma}$

Because capital consists of physical and human capitals, the accumulation of capital written as follows:

$$
\begin{aligned}
& \tilde{\mathrm{k}}(\mathrm{t})=\mathrm{s}_{\mathrm{k}} \tilde{\mathrm{y}}(\mathrm{t})-\left(\delta+\mathrm{n}_{\mathrm{L}}+\mathrm{n}_{\mathrm{A}}\right) \tilde{\mathrm{k}}(\mathrm{t}) \\
& \tilde{\mathrm{h}}(\mathrm{t})=\mathrm{s}_{\mathrm{h}} \tilde{\mathrm{y}}(\mathrm{t})-\left(\delta+\mathrm{n}_{\mathrm{L}}+\mathrm{n}_{\mathrm{A}}\right) \tilde{\mathrm{h}}(\mathrm{t})
\end{aligned}
$$

With $s_{k}$ and $s_{h}$ as the savings rate for the physical and human capital, $\delta$ is depreciation rate, $n_{L}$ is the population growth rate and $n_{A}$ is the technology growth rate.

Production is the final result of an economic activity that utilizes several inputs. The production activity can develop by adding production factors, such as capital and labor which altogether produce an output that has added value. Besides input, the output is also affected by the technology used in the production process. Such a relationship between input and output manifested in a function that is known as the production function. The production function formulated as:

$Q=f(K, L)$

For $Q$ is the output of certain goods in a period, $K$ is the capital used in that period, and $L$ is the labor (Nicholson, 2002). According to the period, the production process classified to short-term production function and long-term production function. In the short-term production process, an output can expand by the addition of one or more inputs, assuming that all other inputs are constant. It is known as marginal physical productivity (Nicholson, 2002). The marginal physical productivity differentiated into two; in capital and labor. The marginal product of capital (MPK) is the additional output resulting from the addition of one capital unit with an endless amount of labor. The marginal product of labor (MPL) is the additional output resulting from employing more labor input assuming that the capital is constant. The addition of labor input in the production process will result in the rise of the output. However, the output will decrease if more labor input added. It is called the diminishing of marginal physical productivity. The diminishing physical productivity occurs in the short-term production function.

Productivity can be used to assess how efficient the resources used. It means more productivity, more goods, and services produced by specific resources. Productivity is the number of goods and services that a worker provides on each of his work hours. Productivity growth is the key to improve the decent standard of living in a country because the standard of living of a 
country depends on the capability of a person to produce the goods and services.

The human capital theory stated that it discusses the investment forms that can be added to human because human is also one of the resources needed in production activity of goods and services in the economy (Becker, 1993). Thus, the investment in human capital, such as education and health is the key to improve the human development which will eventually serve to the increase of the economic output of a country.

Generally, human capital has a vital role in the growth process and economic development. The economic growth and advancement achieved are very much depends on the improvement of capital forming, both physical capital and natural capital. Besides physical and natural capital, human capital is also a crucial factor and a key in the economic growth that can increase productivity.

Becker (1993) further explained that humans are not only resources but also investments that generate returns and their spending are meant to improve the quality and quantity of humans. The added value in humans made when education and skill are useful for a company. The human capital has measured by education and training.

Generally, the investment can be defined as the spending to purchase the capital goods and production pieces of equipment to advance the ability to produce goods and services in the economy. The adding of the capital goods amount makes it possible to produce more goods and services in the future.

Empirically, studies about the linkage between human capital and per capita output done many times, and the findings were contradictive. Barro (1991) and Mankiw et al. (1992) proved that the human capital, measured by education indicator, has a positive impact on the output per capita. However, a study by Benhabib \& Spiegel (1994) shows the opposite result. Nevertheless, recent findings show more consistent results and suitable for the expected theory (Fuente, 2011). According to Fuente \& Doménech (2006), the excellent result with the data quality used will determine the direction of the relationship between human capital and output per capita. Danquah \& Ouattara (2014) adopted the panel data method in the productivity index of Malmquist to analyze the contribution of total human resources to productivity growth. Their study findings revealed the various gift of human resources composition on TFP growth. The proxy of unskilled labors for the secondary and elementary attainment (which was the leading supplier of the economic growth) has a significant effect on the technology in SSA countries, while the skilled labors in the higher education level do several essential roles in the domestic innovation.

Bokana \& Akinola (2017) conducted a study about the effect of productivity from the higher education applicants, higher education outputs and the related productivity gap in certain countries in Sub-Sahara Africa (SSA) within the 1981-2014 period. The finding shows that the applicants of higher education do not give significant positive impact statistically in the productivity growth twenty-one SSA countries. Lebedinski \& Vandenberghe (2013) estimated the effect of education on productivity in the company level using panel data in Belgium. The overall impact of education on productivity was positive and significant, which was in two years 
time period, the college and university graduates labors were more productive elementary education graduates labors.

Fleisher, Hu, Li, \& Kim (2011) studied the education roles on the worker's productivity using company data in five China cities from 1998 to 2000 . The study finding showed that the marginal productivity of educated people was higher than non-educated labor. The estimation of the education findings was significant and positive in two cities in China. Farah \& Sari (2014) conducted a study entitled Human Capital and Productivity. The study explained that human capital was one of the factors that determined the productivity. The analysis result shows that the human capital, which was measured by the education level (Pure Participation Rate - PPR) and health level (Infant Mortality Rate - IMR), has the effect and is significant to explain the varied productivity even though its magnitude is smaller compared to the physical capital. The analysis result also shows that the education variable has more critical compared to the health variable. Aimon (2012) studied the Productivity, Investment on Human Resources, Physical Investment, and Work Opportunity on the Poverty and the Economic Growth in Indonesia. The study finding shows that investment in education and health field can improve human capital productivity and economic growth. Such investment may reduce poverty in Indonesia.

The urgency of this study is to describe the impact of human capital in increasing the economic productivity in Kalimantan Island. In this study, we observed the relationship between education, health, and physical capital investment in improving regional economic productivity. Therefore, through this study, we try to examine and analyze the importance of human capital role in improving productivity to achieve sustainable economic growth.

\section{RESEARCH METHOD}

This is quantitative research. The study objects were provinces in Kalimantan within 2013-2017 time periods. The data used as the analysis materials were secondary data, taken from the Central Agency of Statistics. The data analysis method used was multiple regression analysis methods with panel data method. The calculation result obtained will be tested using the classical assumption test and the statistical test should be fulfilled. Based on the theory, framework, and hypothesis, as well as previous research, a model of the productivity equation was made as below:

PRO $=f(E D U$, HEA, INV $)$

The equations above can be stated in the econometric model to demonstrate the productivity level of provinces in Kalimantan, which was:

$$
\mathrm{PRO}_{i \mathrm{t}}=\beta_{0}+\beta_{1} \mathrm{EDU}_{\mathrm{it}}+\beta_{2} \mathrm{HEA}+\beta_{3} \mathrm{INV}_{\mathrm{it}}+\varepsilon_{\mathrm{it}}
$$

Notes:

$\mathrm{PRO}_{\text {it }}=$ Productivity number-i, in year $\mathrm{t}$

$\mathrm{EDU}_{\mathrm{it}} \quad=$ The Average of Years of education of region number-i, in year $\mathrm{t}$

HEA $_{\text {it }}=$ The Life Expectancy of region number $\mathrm{i}$, in year $\mathrm{t}$

$\mathrm{INV}_{\text {it }}=$ The Gross Fixed Capital Formation of $\backslash \quad$ region number-i, in year $t$

$\varepsilon_{\text {it }} \quad=$ error term

$\beta_{\mathrm{o}} \quad=$ constant

$\beta_{1}, \beta_{2}, \beta_{3}, \beta_{4} \quad=$ estimated regression parameter 
$\mathrm{i} \quad=$ provinces in Kalimantan observed

$\mathrm{t} \quad=$ observation period..

\section{RESULTS AND DISCUSSION}

The equation of the panel data regression for productivity equation model can be written as below (Table 1) :

$\log \mathrm{PRO}_{\text {it }}=-55,24+0,87 \log \mathrm{EDU}_{\mathrm{it}}+30,41 \mathrm{Log}$

$$
\mathrm{HEA}_{\text {it }}+\text { o,03 } \operatorname{LogINV}_{\text {it }}
$$

The data conversion to logarithm was done to reduce the variables' values, so there were value equations between a variable with other variables. The econometric experts often use the way to solve the data problem (Gujarati, 2004).

Table 1. The Result of Multiple Regression Panel Data Method Random Effect Model

\begin{tabular}{|c|c|c|c|}
\hline \multirow{3}{*}{$\begin{array}{c}\text { Independent } \\
\text { Variable }\end{array}$} & \multicolumn{3}{|c|}{ (REM) Approach } \\
\hline & Productivity & & \\
\hline & Coefficient & t-stat & $\begin{array}{c}\text { P- } \\
\text { Value }\end{array}$ \\
\hline $\mathrm{C}$ & -55.24250 & $\begin{array}{l}- \\
5.536518\end{array}$ & 0.0000 \\
\hline LOG_EDU? & 0.878144 & 0.549343 & 0.5886 \\
\hline LOG_HEA? & 30.41350 & $\begin{array}{l}5.102355 \\
* *\end{array}$ & 0.0000 \\
\hline LOG_INV? & 0.030317 & 0.237029 & 0.8149 \\
\hline $\mathrm{R}^{2}$ & 0.720121 & & \\
\hline $\begin{array}{l}\text { Prob } \\
\text { (F-statistic) }\end{array}$ & 0.000005 & & \\
\hline
\end{tabular}

Description:** $\alpha=5 \%$

Source : Data Processed

The equation model 8 used a random effect approach and pooled EGLS (crosssection random effect) method. The random effect was chosen based on the Chow and Hausman Test findings (table 2). The model had passed the classical assumption test.

The result obtained using equation 8 is that the education, health, and investment have a positive effect on productivity level in provinces in Kalimantan. The education level which is the forming factor of the human capital gives a positive impact on productivity improvement in regions of Kalimantan Island. The education level in this study is projected using the data of the average years of education which is one of the components that build the Human Development Index (HDI).

Table 2. Chow and Hausman Test Findings

\begin{tabular}{lccl}
\hline Test & Probability & $\begin{array}{c}\text { Significant } \\
\text { Level } \\
\text { Used }\end{array}$ & Result \\
\hline Chow & 0.1225 & 0.05 & $\begin{array}{l}\text { Common } \\
\text { Effect }\end{array}$ \\
\hline Hausman & 0.7268 & 0.05 & $\begin{array}{l}\text { Random } \\
\text { Effect }\end{array}$ \\
\hline
\end{tabular}

Source : Data Processed

In an analysis, it can be explained that the average years of education can be used as an indicator to assess the quality of the population in receiving the formal education. The average years of education is defined as the total study year of the residents aged 15 years and older who have completed formal education (exclusion of those who repeat classes).

The average years of education are important indicators used as a variable to count the Human Development Index (HDI), especially in the education sector. The positive effect of the education level is indicated by the average years of education of residents aged 15 years and older during the year 2013-2017 which 
have shown an increasing trend from each province in Kalimantan. It can be seen that in West Kalimantan province, the average years of education reached 7.05 years, which indicated an increase from the previous year (6.98 years), followed by Central Kalimantan which reached 8.29 years, indicated an increase from the previous year (8.13 years), South Kalimantan reached 7.99 years, which was increased from the previous year (7.89 years), East Kalimantan reached 9.56 years, which was increased from the previous year (9.24 years, and North Kalimantan which reached 8.62, indicated an increase as well from the previous year (8.49 years). The increase of average years of education in each province in West Kalimantan means that averagely, the residents of West Kalimantan have taken, at least, Junior High School grade 1 as the lowest education, and there are even provinces that have higher average years of education, which are Central and North Kalimantan provinces which reached 8 years, and East Kalimantan which reached 9 years. On the regency/city level, the highest average years of study was reached by Pontianak City with 9.79 years of education in 2017, which means the average population in Pontianak City is able to study up to Senior High School grade 3 (three). While the lowest average years of education was in Kayong Utara Regency which only reached 5.85 years in 2017.

The human growth development in North Kalimantan over the past year is quite progressive compared to four other provinces in Kalimantan region. It is indicated by the human development achievement in North Kalimantan which took the second place in Kalimantan, after East Kalimantan. Besides, the HDI growth rate is quite high, even above the average growth rate of the National HDI. As a relatively new province, the human development achievement of North Kalimantan is considered good, because it ranks second in Kalimantan region and twentieth at National level. However, the magnitude and the HDI rank of North Kalimantan only differ slightly with the Central Kalimantan and South Kalimantan. Compared to Central Kalimantan's HDI, which has higher growth rate, there is a chance that the human growth achievement North Kalimantan can be exceeded by Central Kalimantan.

To improve the HDI in education sector, the Ministry of Education and Culture has tried several efforts by increasing the average years of education of residents aged 15 years and older. One of the efforts is to reduce the dropout rate and increase the number of study continuing between levels of education. Another effort that is also carried out is to improve access and quality of early childhood education (ECED), increase the participation of good quality elementary education, improve access and quality of secondary education, improve the access and competitiveness of higher education, and improve the quality of teachers and education staffs. The positive relationship of the education level, projected by the average of years of education, with the productivity level in provinces in Kalimantan indicates that the longer a person study, it is assumed that the higher his education is. Thus, along with the increase of the average length of study in West Kalimantan, South Kalimantan, Central Kalimantan, East Kalimantan, and North Kalimantan provinces, a good and positive sign is shown that the more people have had education, resulting in a productivity increase of the regions in Kalimantan IslandThe study finding fits the theory of "Human Capital", that according to the theory, education affects the 
economic growth through the improvement of skills and productivity of the labors. The fast economic growth in countries in Asia and the progressive changes in production towards the industry and high-tech services allow more demands from the business world of the skilled and educated human resources. The human resources skills as labors are needed to finish tasks, improve organization quality, and support economic growth (Sulistyowati, Harianto, Priyarsono, \& Tambunan, 2010). And in accordance with the endogen growth theory, especially supported and or developed by Lucas Jr (1988), (Romer, 1990), Mankiw et al. (1992) who argue that the increase of human capital (healthy and skilled labor) will lead to the improvement of productivity and as the effect will produce growth.

Education investment will improve the quality of the human resources which is shown by the increase of the education and the skill of the labors. The improvement of the education and skill will encourage the work productivity increase in labor. The company will gain more result by employing labor with higher productivity, thus the company would want to pay a higher salary/wage to the labor. Eventually, someone who has higher productivity will have more prosperity, seen by the increase in his income and consumption. The low of productivity of the poor labor probably is caused by the lack of their access to education.

The important role of human capital in productivity growth is widely recognized in the economic literature since Schultz (1961) contribution. Schultz (1961) in his speech entitled Investment in Human Capital stated that the education, knowledge, health, and skill are the forms of human capital. Investment in human capital will generate a return in the future. The improvement in the education of the people will encourage productivity and growth of a country.

This study finding is in line with the research by Leeuwen (2007) who measured the human capital by their average years of education. The analysis which was done using a time series method showed a positive relationship between the human capital and economic growth in Indonesia in the $20^{\text {th }}$ century. Alisjahbana (2009) used the average education attainment per person and the finding showed that the contribution of human capital to the economic growth was 30 percent. Farah \& Sari (2014) reported that human capital that is measured by education level (literacy rates and illiteracy rates in the Elementary, JHS, and SHS) has the positive and significant effect toward productivity in provinces in Indonesia in 19962010 time periods. Other studies that are in line with the result is the study by Islam et al. (2016), Arshad \& Malik (2015) and Ismail et al. (2014) in Malaysia, the study by Wang \& Liu (2016) in China, the study by Reza \& Widodo (2013) in Indonesia, the study by Kingdom, Hakooma, \& Seshamani (2017) in Zambia, and the study by (oejoto et al. (2017) in Southeast Asia. While the studies whose findings state the education effect are negative and insignificant are the study by Bokana \& Akinola (2017) in Africa, and study by Wang \& Liu (2016) in China.

Besides education, health also plays important role in increasing productivity. It is assumed that the healthier someone, the more productive he can be, and the more productive someone, the more income he may gain. Basedon UNDP in its report of the Human Development Index, health is one of the factors. 
The health level can be identified by measuring life expectancy. From the estimation of panel data regression, we found that the variable human capital that was measured by the health level (life expectancy) has the positive and significant effect toward the productivity level in Provinces in Kalimantan.

In an analysis, it can be explained that the good quality of human resources is urgently needed to accelerate the national development. One very important aspect in improving the quality of human resources is the health aspect. Physical and mental health need to be fulfilled so that human resources can work, create, and be productive, to support the process and dynamics of the economic development of a country/region.

The health level of the population in a province can be seen from the number of Infant Mortality Rate (IMR) and the life expectancy of the population. The IMR in West Kalimantan in 2017 ( 38 deaths per 1000 live births) is higher than Indonesia's IMR which reaches 34 deaths per 1000 live births. Compared to other provinces in Kalimantan, West Kalimantan is below East Kalimantan with only 21 deaths per 1000 live births, while the Central and South Kalimantan IMR are still quite high at 49 and 44 deaths per 1000 live births, consecutively. IMR of West Kalimantan is to some degree showing a good progress in a period of 10 years. Over the past decade, the West Kalimantan IMR has gradually decreased.

Similar conditions also occur in the under-five mortality rate $\left(\mathrm{U}_{5} \mathrm{MR}\right)$ in West Kalimantan which keeps declining. The results of IDHS in 1971 showed that the $\mathrm{U}_{5} \mathrm{MR}$ in West Kalimantan reached 216 deaths per 1.0oo live births and in 1999 IDHS it declined to 39 deaths per 1.000 live births. The improvement in health aspect in West Kalimantan is accompanied by an increase in life expectancy, which was noted from 69.06 years (in 2010) to a longer ager of 69.92 years (2017).

The same thing occurs in the Life Expectancy at birth that represents the longevity and healthy life dimensions, which continue to increase from year to year. During the period of 2010 to 2017, West Kalimantan has succeeded in increasing the Life Expectancy to grow by 0.18 percent per year. In 2010, Life Expectancy at birth in West Kalimantan was only 69.90 years, and in 2017 it reached 69.92 years. This condition was also followed by other provinces such as Central Kalimantan which reached 69.57 years and increased to 69.59 years in 2017, South Kalimantan which reached 67.92 years and increased to 68.02 years in 2017, East Kalimantan which reached 73.68 years and increased to 73.70 years in 2017, and North Kalimantan which reached 72.43 years and increased to 72.47 years in 2017.

Regarding the health aspect, the government has implemented various health programs to improve health status of the community, especially providing an easy access to public health services such as health centers with the main goal is to reduce community morbidity, maternal and infant mortality, prevalence of malnutrition and underweight children, and increase life expectancy. Government efforts through development programs that have been done include increasing public access to health facilities and improving health services that are standardize, quality, equitable, and affordable by providing free health services to the poor; providing competent health resources by distributing health workersevenly throughout the region, improving health facilities and infrastructure by 
constructing health centers, hospitals, village health centers, and maternal and child health services, as well as providing affordable medicine to the community.

The positive and significant relationship between health variable, projected by the life expectancy, with the productivity level is suitable with the hypothesis that the health partially affects the productivity level in provinces in Kalimantan. Therefore, the number of government investment in education and health depends on the GERD per capita received. It is in accordance with the Wagner Law which stated that in an economy if the income per capita increases, the government spending will relatively increase too. When the government's spending on the health investment increase, the health infrastructure will be better and it will eventually improve the health of the society. With the health of the society improving, the life expectancy, which is the component that forms the HDI in the health sector, will be better. According to the data of CAS, the life expectancy in provinces in Kalimantan from 2013 to 2017 is increasing. From the data, it can be assumed that the health in West Kalimantan, South Kalimantan, Central Kalimantan, East Kalimantan, and North Kalimantan provinces have become better because of the higher life expectancy.

Todaro, M.P., \& Smith (2006) suggested that human capital can be invested through education and health. The education has an important role in the economic skill to adopt modern technology and to build capacity for sustainable growth. Health is a prerequisite to improving productivity. Thus, education and health can also be viewed as important elements in development and growth as the input for the aggregate production function. Health also supports the human capital development. Health is the basis of work productivity and capacity to improve education. A physically and mentally healthy labor will be more productive in working and will gain more income. Good health is an important input for human capital in increasing productivity.

Kingdom, Hakooma, \& Seshamani (2017) tested the impact of human capital on the economic growth in Zambia. The estimated long-term model showed that the human capital in a form of health, projected by the public spending on health, is the main contributor of the increase of the real GDP per capita, followed by the human capital education projected by the senior high school education. This finding is consistent with the endogenous growth theory which suggested that the improvement in human capital in a form of skilled and healthy labor will increase productivity.

Sniukienè \& Matuzevičiūtè (2018) in their study concluded that the human capital, in this case, spending on the health and education, has the positive and significant effect toward the productivity in European Union country members. Also, Bloom, Canning, \& Sevilla (2001) reported that health significantly affects productivity. Other studies are studies by Wang \& Liu (2016) in China, the study by Aldosari et al. (2014) in Saudi Arabia, the study by Xiaoqing (2005) in China, study by Kingdom et al. (2017) in Zambia, and study by Arshad \& Malik (2015) in Malaysia.

Another variable, investment, also has a positive effect as a determinant factor on the increase of regional economic productivity. Generally, the capital has an important role in the growth and development of the economy. 
The economic growth and development achieved very much depend on the increase of the capital form, both physical and natural capitals. Besides physical and natural capitals, human capital also plays an important role and becomes the key to the economic growth and productivity increase.

In an analysis, it can be explained that the positive impact demonstrated by the physical capital investment, in this case was the component of Gross Fixed Capital Formation (GFCF) on the regional economy productivity, can also be interpreted as an illustration of various goods and services that are partly used as physical investment (capital). In which the component of physical capital investment also shows an increase, both nominal and physical. According to this, it can be seen that overall growth of physical capital investment in 2013-2017 increased from 2.24 percent (2013) to 2.33 percent (2017).

The growth rate of gross fixed capital formation (GFCF) in each province in Kalimantan shows a trend of development that greatly varies between years with the subcomponent building as the component that has the largest proportion in the formation of fixed capital. The growth in the building sector, although tending to increase, remains relatively stable compared to other growth in the GFCF sub-component. Non-building proportions of gross fixed capital formation relatively fluctuated during the 2013-207 time period. Changes in these proportions are much influenced by the growth of each GFCF sub-component. In general, during the period of 2013-2017 the growth of GFCF fluctuated, in which the highest growth occurred in 2015, reaching a magnitude of 5.70 percent, and the lowest growth occurred in 2016 which was only 0.54 percent.
Meanwhile, seen from its growth, the nonbuilding sub-component show very varied patterns between years. In the period of 2013 to 2017 the growth of buildings tended to fluctuate. In 2013, the growth of non-building components was growing and reached 7.21 percent. However, in the following years, it began to fluctuate again, which increased by 6.89 percent (2015), minus 3.o percent (2016), and minus 2.84 percent (2017). Te 'real' growth of building sub-component in 2013 was 4.93 percent. This number has increased to 10.62 percent in 2014, but experienced a slowdown in 2015 with a growth of only 5.04 percent. As happened in South Kalimantan province, the non-construction sub-component showed a varied pattern between years. In 2013 it increased to $5.71 \%$ and in 2014 it increased to $6.10 \%$. These increases were partly due to the increasingly aggressive production of cement companies in Tabalong. Despite experiencing a slowdown in 2015 and 2016, this sub-component increased again and even reached 4.66 percent growth meanwhile in Central Kalimantan, the growth of non-building sub-component showed a fluctuating pattern. The highest growth in nonbuilding sub-component happened in 2014 which was 5.20 percent and experienced a slowdown in 2015 to 3.65 percent. In 2016, its growth increased again to 4.41 percent, but slowed in 2017 to 4.26 percent. In general, the growth of GFCF in 2017 was only 4.02, which was slower compared to the previous year which grew by 5.25 percent.

According to Saepudin (2013), investment growth is an important element in the economic growth process in a country/region. This is demonstrated by the estimation result, that the investment growth has a positive and significant effect on the economic growth in provinces in Indonesia. The relationship between the investment and economic growth is coherent 
(unidirectional relationship); if investment growth is increasing, the economic growth will also be increased. This is in line with the principle in economic growth that the capital growth (investment) is in line with the economic growth (output). The capital growth positively correlates with economic growth. The relationship by Harrord-Domar was implied by how much the capital addition needed for the economy to grow as expected. This statement was formulated as $\Delta k / \Delta y$, and called ICOR (Incremental Capital Output Ratio).

As stated by Solow, capital is important economy output determinant because the capital stock may change time to time and such changes can lead to economic growth. Investment as the part of the capital will lead to the spending to business developing and spending on new tools, which will cause the capital stock to increase and as the result, boost the economic growth.

Mankiw, et al (1992) conducted research using 2 kinds of capital, which were the physical capital and human resources capital in 98 countries in $1960-1985$ time periods as the average. From both capitals, the physical investment plays a more important role in the economic growth compared to the human resources investment. They also reported that the higher the development structure level of a country, the human resources capital becomes more important in pushing the economic growth.

In a study conducted by Brata (2002), it is reported that qualified human development will encourage economic growth and vice versa. While in a study by Ranis, Frances, \& Alejandro (2000), per capita income growth is significantly affected by literacy rates, life expectancy, and domestic investment. The positive effect of the physical capital variable (investment) on the productivity is in accordance with the study by Soejoto et al. (2017) in Southeast Asia, the study by Reza \& Widodo (2013) in Indonesia, the study by Xiaoqing (2005) in China, but is contradictive with the study by Olayemi (2012) in Nigeria which stated that the forming of Gross Capital shows long-term negative relationship with the productivity rate of the industrial sector.

\section{CONCLUSION}

This study concludes that the education level, health level, and investment variables have a positive effect on the level of productivity in provinces in Kalimantan. It implies that the role of human capital forming remains important in supporting economic productivity in every region. Therefore, the regional and central government should play a role in creating and determining the developing strategy that prioritizes the human capital role by improving the human resources quality and investment support as a strategy in sustainable development model in Indonesia.

\section{REFERENCE}

Aimon, H. (2012). Productivity, Human Resource Investment, Physical Investment, Job Opportunities for Poverty and Economic Growth in Indonesia. Journal of Economic Studies, 1 (1), 209-218.

Aldosari, M., Ibrahim, Y., Manab, N. A., \& Islam, R. (2014). Foreign Workers Satisfaction with Cooperative Health Insurance in Saudi Arabia. Advances in Natural and Applied Sciences, 8(9), 101-108.

Alisjahbana, A. S. (2009). Revisiting Indonesia's Sources of Economic Growth and Its Projection Towards 2030. Working Paper in Economics and Development Studies

Arshad, M. N. M., \& Malik, Z. A. (2015). Quality of Human Capital and Labor Productivity : A Case of Malaysia. 
International Journal of Economics, Management and Accounting, 23(1), 37-55.

Barro, R. . (1991). Economic Growth in a Cross Section Countries. Quarterly Journal of Economics, 106, 407-443.

Becker, G. S. (1993). Human Capital : A Theoretical and Empirical Analysis with Special Reference to Education. University of Chicago Press.

Benhabib, J., \& Spiegel, M. M. (1994). The Role of Human Capital in Economic Development Evidence From Aggregate Cross-Country Data. Journal of Monetary Economics, 34(2), 143-173.

Bloom, D. E., Canning, D., \& Sevilla, J. (2001). The Effect of Health on Economic Growth: Theory and Evidence. Cambridge.

Bokana, K. G., \& Akinola, G. W. (2017). Productivity Effects of Higher Education Human Capital in Selected Countries of Sub-Saharan Africa. Zb. Rad. Ekon. Fak. Rij, 35(1), 173-198. https://doi.org/10.18045/zbefri.2017.1.173

Brata, A. G. (2002). Human Development and Regional Economic Performance in Indonesia. Journal of Development Economics, 7 (2), 113-122.

Danquah, M., \& Ouattara, B. (2014). Productivity Growth, Human Capital and Distance to Frontier in Sub-Saharan Africa. Journal of Economic Development, 39(4), 27-48.

Devadas, U. M. (2015). Comprehensive Literature Review on Human Capital Investments Theory: What' $s$ in it? Kelaniya Journal of Human Resource Management, 10(01), 20-44.

Farah, A., \& Sari, E. P. (2014). Human Capital and Productivity. Journal of Economics and Policy, 7 (1), 22-28. https://doi.org/10.15294 / trace. v7i2.3840

Fleisher, B. M., Hu, Y., Li, H., \& Kim, S. (2011). Economic transition, higher education and worker productivity in China. Journal of Development Economics, 94(1), 86-94. https://doi.org/10.1016 /j.jdeveco.2010.01.001

Fuente, A. De, \& Doménech, R. (2006). Human Capital in Growth Regressions: How Much Difference Does Data Quality Make? Journal Ofthe European Economic Association, 4(1), 1-36.

Fuente, A. de la. (2011). Human Capital and Productivity. Barcelona Economics Working Paper Series. Retrieved from http://pareto.uab.es /wp /2011/86011.pdf

Gujarati, D. N. (2004). Basic Econometrics Fourth Edition. Singapore: McGraw-Hill.
Islam, R., Ghani, A. B. A., Kusuma, B., \& Theseira, B. B. (2016). Education and Human Capital Effect on Malaysian Economic Growth. International Journal of Economics and Financial Issues, 6(4), 1722-1728.

Ismail, R., Saukani, M. N. M., \& Bakar, N. T. A. (2014). Human Capital and Regional Wage Differentials in Malaysia. Actual Problems of Economics, 5(155), 328-338.

Ismail, R., \& Yussof, I. (2010). Human Capital and Income Distribution in Malaysia: A Case Study. Journal of Economic Cooperation and Development, 31(2), 2546.

Kingdom, U., Hakooma, M. R., \& Seshamani, V. (2017). The Impact of Human Capital Development on Economic Growth in Zambia: an Econometric Analysis. International Journal of Economics, Commerce and Management, V(4), 71-87.

Lebedinski, L., \& Vandenberghe, V. (2013). Assessing education's contribution to productivity using firmlevel evidence. International Journal of Manpower. https://doi.org/10.1108/IJM-o6-2012-009o

Leeuwen, B. van. (2007). Human Capital and Economic Growth in India, Indonesia and Japan. Netherlands.

Lucas Jr, R. E. (1988). On the Mechanics of Economic Development. Journal of Monetary Economics, 22, 3-42.

Mankiw, N. G. (2005). Macroeconomics (6th ed.). New York: Worth Publishers.

Mankiw, N. G., Romer, D., \& Weil, D. N. (1992). A Contribution to the Empirics of Economic Growth. The Quarterly Journal of Economics, 407-437. https://doi.org/10.1016/j.jpolmod.2014.01.001

Nicholson, W. (2002). Intermediate Microeconomics and its Application (Eighth). Jakarta: Erlangga.

Olayemi, S. O. (2012). Human Capital Investment and Industrial Productivity in Nigeria. International Journal of Humanities and Social Science, 2(16), 298307.

Ranis, G., Frances, S., \& Alejandro, R. (200o). Economic Growth and Human Development. World Development, 28(2), 197-219.

Reza, F., \& Widodo, T. (2013). The Impact of Education on Economic Growth in Indonesia. Journal of Indonesian Economy and Business, 28(1), 23-44.

Romer, P. M. (1990). Endogenous Technological Change. Journal of Political Economy, 98(5), 71-102.

Saepudin, T. (2013). Growth of Human Capital and InterRegional Economic Growth in Indonesia. 
In National Education Seminar: Indonesian Economic Optimism 2013, Between Opportunities and Challenges (pp. 21-38).

Schultz, T. W. (1961). Investment in HumanCapital.pdf. The American Economic Review, 51(1), 1-17.

ŠNIUKIENĖ, A. M., \& MATUZEVIČIÜTĖ, K. (2018). Impact of Human Capital Development on Productivity Growth in EU Member States. Business, Management and Education, 16(1), 112.

Soejoto, A., Cahyono, H., \& Solikhah, N. (2017). Effect of Solow Variable to the Economic Growth in Southeast Asia. International Journal of Economics and Financial Issues, 7(2), 277-282.

Solow, R. M. (1956). A Contribution to the Theory of Economic Growth. The Quarterly Journal of Economics, 70(1), 65-94.
Sulistyowati, N., Harianto, Priyarsono, D.., \& Tambunan, M. (2010). The Impact of Educational Investment on the Economy and Community Welfare of Districts and Cities in Central Java. Journal of Organization and Management, 6 (2), 158-170.

Todaro, M.P., \& Smith, S.. (2006). Economic Development (Ninth). Jakarta: Erlangga.

Wang, Y., \& Liu, S. (2016). Education, Human Capital and Economic Growth: Empirical Research on 55 Countries and Regions ( 1960-2009). Theoretical Economics Letters, 6, 347-355.

World Bank. (2001). World Development Report 2001. Washington: The World Bank.

Xiaoqing, X. (2005). Investment in Physical Capital , Investment in Health and Economic Growth in China. Investment Management and Financial Innovations, 2(1), 23-29. 